\title{
PERAMALAN JUMLAH PENUMPANG PESAWAT DI BANDAR UDARA INTERNASIONAL JUANDA MENGGUNAKAN METODE EXPONENTIAL SMOOTHING EVENT-BASED
}

\section{Forecasting The Number of Aircraft Passengers at Juanda International Airport Using Exponential Smoothing Event-Based Method}

\author{
Yuniar Farida ${ }^{1 *}$, Suyesti Yusi ${ }^{2}$, Dian Yuliati ${ }^{3}$ \\ 1,2,3 Program Studi Matematika, Fakultas Sains dan Teknologi, UIN Sunan Ampel Surabaya \\ Jln. Ahmad Yani No. 117, Surabaya, 60237, Indonesia \\ Corresponding author e-mail: 1*yuniar_farida@uinsby.ac.id
}

\begin{abstract}
Abstrak
Kenaikan jumlah penumpang pesawat terjadi pada saat-saat tertentu seperti Hari Raya Idul Adha, Hari Raya Idul Fitri, dan Libur Natal. Tentunya kenaikan jumlah penumpang yang berlebihan berpotensi mengakibatkan kepadatan lalu lintas penerbangan yang berlebihan sehingga dapat menyebabkan keterlambatan penerbangan, menurunnya performa tingkat pelayanan bandara dan dampak lainnya. Penelitian ini bertujuan untuk meramalkan jumlah penumpang pesawat di Bandar udara Internasional Juanda menggunakan metode Exponential Smoothing EventBased. Metode Exponential Smoothing Event-Based merupakan metode peralaman yang mempertimbangkan special event dengan menggunakan metode Exponential Smoothing sebagai perhitungan awal. Penelitian ini menggunakan data jumlah penumpang dari Januari 2014 hingga Desember 2020. Dari model peramalan dihasilkan MAPE sebesar $11,8905 \%$ dan MSE 4202958561,0706 sehingga peramalan yang dihasilkan dapat dikategorikan baik.
\end{abstract}

Kata Kunci : Penumpang Pesawat, Special Event, Exponential Smoothing Event-Based.

\begin{abstract}
The number of airplane passengers increases at certain times, such as Eid al-Adha, Eid al-Fitr, and Christmas holidays. Of course, an excessive rise in the number of passengers can cause extreme flight traffic density, which can cause flight delays, decreased airport service level performance, and other impacts. This study predicts the number of aircraft passengers at Juanda International Airport using the Exponential Smoothing Event-Based method. The Exponential Smoothing Event-Based method is a forecasting method that considers special events using the Exponential Smoothing method as the initial calculation. This study uses data on the number of passengers from January 2014 to December 2020. From the forecasting model, MAPE is 11.8905\%, and MSE is 4202958561.0706, so that the resulting forecast can be categorized as good.
\end{abstract}

Keywords: Airplane Passengers, Special Event, Exponential Smoothing Event-Based. 


\section{PENDAHULUAN}

Salah satu moda transportasi yang saat ini banyak diminati masyarakat adalah moda transportasi udara karena kemudahan dan kecepatannya dalam menjangkau berbagai wilayah baik domestik maupun internasional, sehingga lebih menunjang aktivitas masyarakat serta relative nyaman dibanding transportasi lainnya [1]. Pada saat libur nasional tertentu (special event) seperti saat menjelang dan sesudah Hari Raya Idul Fitri, Hari Raya Idul Adha dan Libur Natal, terjadi lonjakan jumlah penumpang. Kenaikan jumlah penumpang yang berlebihan dapat mengakibatkan kepadatan lalu lintas pada penerbangan sehingga dapat menyebabkan keterlambatan penerbangan, pengaruh tingkat pelayanan pada saat di bandara dan penyebab lainnya [2].

Bandar Udara Internasional Juanda Surabaya merupakan bandar udara tersibuk ke-5 di Indonesia [3]. Meski demikian, Bandar Udara Internasional Juanda memiliki kualitas layanan terbaik nomor tiga di Indonesia dengan meraih penghargaan " 3 rd place tie Best Airport" pada tahun 2017. Setiap tahun, rata-rata jumlah penumpang yang dilayani sekitar $15-25$ juta penumpang [4]. Jumlah penumpang tertinggi terjadi pada saat special event seperti pada saat menjelang dan sesudah Hari Raya Idul Fitri, Hari Raya Idul Adha dan Libur Natal. Pada tahun 2016, saat Hari Raya Idul Fitri terdapat jumlah penumpang sebanyak 825.715 penumpang, padahal jika bulan-bulan biasa jumlah penumpang hanya berkisar $500.000-600.000$ penumpang. Pada saat Hari Raya Idul Adha, jumlah penumpang sebesar 649.375 dan pada saat Libur Natal jumlah penumpang sebanyak 693.048. Oleh karena itu, untuk mengantisipasi terjadinya lonjakan jumlah penumpang pada special event, sangat diperlukan peramalan penumpang sehingga pihak bandara maupun maskapai dapat menyiapkan segala kebutuhan untuk melayani penumpang dengan maksimal dengan mempersiapkan fasilitas-fasilitas tambahan seperti, menyiapkan pesawat guna untuk penerbangan ekstra, ruang tunggu yang lebih banyak, dan tempat parkir yang lebih luas.

Beberapa metode peramalan yang mengakomodir efek special event atau event-based (metode yang dapat menyarankan bahwa data bisa terjadi peristiwa fluktuasi yang signifikan dan terjadi pada waktu-waktu tertentu) diantaranya adalah metode Decomposition, Moving Average dan Single Exponential Smoothing. Metode Dekomposisi merupakan metode peramalan yang didasarkan pada asumsi bahwa apa yang akan terjadi memiliki pola yang sama dengan yang terjadi sebelumnya [5]. Metode Moving Average merupakan metode peramalan dengan mengambil nilai rata-rata dari sekelompok data pada masa lalu untuk dilakukan peramalan pada periode yang akan datang [6]. Metode Single Exponential Smoothing suatu metode time series dengan pemberian bobot dari data yang terbaru dan perhitungannya diperoleh dari penurunan bobot yang lama, dan untuk tingkat penurunannya ditentukan dari parameter pemulusan [7].

Beberapa penelitian yang mengakomodir efek special event, diantaranya dilakukan oleh [8] melakukan peramalan mengenai permintaan dan perencanaan produksi di PT. Coca-Cola dengan mempertimbangkan variable pengaruh special event, menggunakan 4 (empat) metode, yakni Winter Exponential Smoothing, Decomposition, Exponential Smoothing Event-Based dan Moving Average Event Based. Dari keempat metode tersebut, yang memiliki nilai MAPE terkecil adalah metode Moving Average Event-Based dan Exponential Smoothing Event-Based dengan nilai MAPE untuk metode Moving Average Event-Based produk coca-cola $193 \mathrm{ml}$ adalah 5\%, sprite $200 \mathrm{ml}$ adalah 9\%, Fanta Strawberry $200 \mathrm{ml}$ adalah 9\%, sprite $295 \mathrm{ml}$ adalah 5\%, Fanta soda water $295 \mathrm{ml}$ adalah $6 \%$, freastea jasmine $220 \mathrm{ml}$ adalah $6 \%$. dengan nilai MAPE untuk metode Exponential Smoothing Event-Based produk coca-cola $193 \mathrm{ml}$ adalah 5\%, sprite $200 \mathrm{ml}$ adalah $10 \%$, Fanta Strawberry $200 \mathrm{ml}$ adalah $9 \%$, sprite $295 \mathrm{ml}$ adalah $5 \%$, Fanta soda water $295 \mathrm{ml}$ adalah $6 \%$, freastea jasmine $220 \mathrm{ml}$ adalah $6 \%$. Hasil penelitian menunjukkan bahwa special event memiliki kontribusi yang signifikan dalam mempengaruhi permintaan produk serta dapat melakukan suatu penghematan dari total biaya sebesar $40 \%$ dalam perencanaan produksi.

Penelitian yang dilakukan oleh [9] meramalan penjualan bahan bakar pesawat yakni avtur dengan mempertimbangkan special event dan hasil yang diperoleh adalah DPPU Bandara Internasional Lombok Grup menggunakan metode Moving Average Event-Based dan nilai MAPE yang didapatkan 7,72\%, pada Eltari Group menggunakan metode Exponentian Smoothing Event-Based dan nilai MAPE yang didapatkan 8,92\%, dan di DPPU Juanda serta Ngurah Rai untuk meramalkan menggunakan metode Decomposition dengan nilai MAPE yang dihasilkan dari masing-masingnya adalah 5,59\% dan 3,35\%.

Penelitian yang dilakukan oleh [10] meramalkan jumlah penumpang pesawat di Bandara Internasional Ahmad Yani. Menggunakan 2 (dua) metode, yakni metode Holt Winter's Exponential smoothing dan metode Exponential Smoothing Event-Based. Hasil model peramalan menunjukkan bahwa metode Holt Winter's

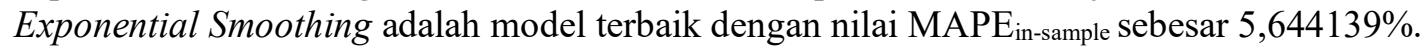


Penelitian yang dilakukan oleh [11] membandingkan antara metode Winter Eksponential Smoothing dan Metode event based dalam meramalkan jumlah penjualan produk A dan produk B dari PT. X. Dari model peramalan diperoleh bahwa metode Winter Exponensial Smoothing menghasilkan peramalan yang lebih baik dengan MAPE yang lebih kecil, yakni $0,76 \%$ untuk produk A dan $0,64 \%$ untuk produk B. Penelitian yang dilakukan oleh [12] membandingkan metode Exponential Smoothing Event-Based dan metode Winter's Exponential smoothing dalam meramalkan jumlah penumpang kedatangan di Pelabuhan penyebrangan Gorontalo. Dari model peramalan diperoleh hasil bahwa metode Exponential Smoothing Event-Based lebih baik dalam meramalkan karena mempunyai nilai MAPE yang kecil, yakni 19,5916\%.

Berdasarkan beberapa penelitian terdahulu, metode Exponential Smoothing Event-Based merupakan metode yang baik dalam meramalkan sesuatu dengan efek kejadian khusus, sehingga dalam penelitian ini menggunakan metode Exponential Smoothing Event-Based untuk meramalkan jumlah penumpang pesawat dengan memperhatikan special event pada hari-hari besar yang memungkinkan terjadinya lonjakan penumpang. Penelitian ini diharapkan memberikan kontribusi informasi bagi pihak Bandar Udara Internasional Juanda untuk mengantisipasi kemungkinan terjadinya lonjakan jumlah penumpang pada saat momen Hari Raya Idul Fitri, Hari Raya Idul Adha dan Libur Natal. Dengan demikian, meskipun terjadi lonjakan penumpang saat special event, Bandar Udara Internasional Juanda masih bisa melayani penumpang dengan baik karena sudah ada upaya antisipasi.

\section{METODE PENELITIAN}

\subsection{Peramalan menggunakan metode Exponential Smoothing}

Peramalan adalah memperkirakan besar atau jumlah dari sesuatu pada masa mendatang menggunakan data yang sudah ada pada masa sebelumnya kemudian dianalisis dengan cara alamiah dan cara khusus menggunakan metode statistic [13]. Tujuan dilakukan peramalan adalah untuk mengurangi sesuatu yang tidak pasti pada masa yang mendatang. Menurut [14], metode peramalan terbagi menjadi dua kategori utama, yaitu metode kualitatif dan metode kuantitatif. Metode kualitatif diperoleh dari pendapat-pendapat para ahli yang digunakan sebagai pertimbangan dalam mengambil suatu keputusan hasil dari peramalan yang sudah dilakukan. Dalam metode kualitatif dilakukan apabila data masa lalu tidak tersedia, maka tidak dapat dilakukan. Namun, jika data pada masa lalu tersedia, lebih efektif jika menggunakan peramalan dengan metode kuantitatif. Dalam penelitian ini penulis menggunakan metode kuantitatif.

Dalam meramalkan jumlah penumpang pada special event, penelitian ini menggunakan metode Smoothing. Metode smoothing merupakan metode peramalan yang menggunakan data pada masa lampau dengan mengambil nilai rata-rata nilai beberapa tahun untuk meramalkan tahun yang akan datang [15]. Metode smoothing dibagi menjadi dua bagian, yaitu metode untuk perataan (Average) dan metode sebagai pemulusan exponential (Exponential Smoothing). Metode untuk perataan (Average) menggunakan pembobotan yang sama terhadap nilai-nilai observasi [16], sedangkan metode exponential (Exponential Smoothing) menggunakan pembobotan yang beda menggunakan data pada masa lampau dan pembobotnya menurun secara exponential [17]. Karena dalam data jumlah penumpang bandar udara mengandung pola musiman maka penelitian saat ini menggunakan menggunakan exponential smoothing method [18].

Exponential smoothing adalah suatu metode time series dengan pemberian bobot dari data yang terbaru. Maka perhitungannya diperoleh dari penurunan bobot yang lama, dan untuk tingkat penurunannya ditentukan dari parameter pemulusan [9]. Bobot yang dimaksud adalah nilai $\alpha$, nilai $\alpha$ digunakan untuk data yang terbaru dan untuk data sebelumnya menggunakan $\alpha(1-\alpha)$. Nilai konstanta dari pemulusan nilai $\alpha$ dapat dipilih diantara nilai 0 dan 1 , karena berlaku $0<\alpha<1$ [19]. Sehingga rumus exponential smoothing didapatkan persamaan (1).

$$
F_{t+1}=a X_{t}+(1-a) F_{t}
$$

Dimana:

$$
\begin{array}{ll}
F_{t+1} & =\text { Peramalan pada periode sebelumnya }(\mathrm{t})+1 \\
a & =\text { Suatu konstanta dari pemulusan }(0<a<1) \\
X_{t} & =\text { Data aktual yang terjadi pada periode ke-t } \\
F_{t} & =\text { Peramalan yang terjadi pada periode ke-t }
\end{array}
$$




\subsection{Event Based}

Event based merupakan suatu metode peramalan yang mempertimbangkan special event di waktuwaktu tertentu. Artinya, dengan menggunakan metode event based dapat mengetahui tinggi rendahnya jumlah penumpang pesawat berdasarkan dari masing-masing indeks event yang diperoleh. Karena menggunakan metode peramalan Exponential Smoothing dapat dinamakan Exponential Smoothing Event Based.

Langkah pertama untuk menghitung metode exponential smoothing event based adalah menghitung dengan menggunakan metode single exponential smoothing sebagai dasarnya. Artinya, untuk menghitung metode Event Based maka hal yang harus dilakukan adalah melakukan perhitungan dari metode single exponential smoothing terlebih dahulu [8]. Kemudian dilakukan perhitungan untuk mencari indeks event pada waktu-waktu tertentu yang didalamnya memuat special event, dengan menggunakan persamaan (2). Smoothing Event Based.

$$
I_{t}=\frac{X_{t}}{F_{t}}
$$

Dimana:

$\boldsymbol{I}_{\boldsymbol{t}}=$ Indeks event yang terjadi pada periode $\mathrm{t}$ dan didalamnya terdapat special event.

Setelah didapatkan nilai dari Indeks Event, kemudian dirata-rata dari tiap-tiap special event agar mendapat nilai Grup Indeks. Fungsi dari Grup Indeks adalah untuk faktor pengali dan apabila telah didapatkan hasil faktor pengalinya, maka dapat dilakukan peramalan Exponential Smoothing Event Based dengan menggunakan persamaan (3).

$$
P_{t+1}=G_{t+1}\left[a X_{t}+(1-a) F_{t}\right]
$$

Dimana:

$\boldsymbol{P}_{\boldsymbol{t}+\mathbf{1}}=$ Peramalan yang diperoleh dari Indeks Event pada periode $\boldsymbol{t}+\mathbf{1}$

$G_{t+1} \quad=$ Grup Indeks dari periode $t+1$

\subsection{Ukuran Kesalahan (ERROR)}

Dalam melakukan sebuah penelitian untuk menguji apakah model yang dihasilkan adalah model yang baik maka, perhitungan error adalah peran yang sangat penting untuk mengetahui keakuratan dari suatu model. Apabila setelah dilakukan peramalan dan diperoleh nilai error maka, dapat dilihat jika semakin kecil nilai error yang diperoleh dapat dikatakan metode tersebut metode yang baik untuk digunakan [20]. Untuk mengukur eror dari suatu model [21], pada penelitian ini yang digunakan adalah dengan mengukur nilai Mean Square Error (MSE) dan Mean Absolute Precentage Error (MAPE).

Untuk menghitung nilai dari Mean Square Error (MSE) menggunakan persamaan (4).

$$
M S E=\frac{\sum_{i=1}^{n}\left(X_{t}-F_{t}\right)^{2}}{n}
$$

Dimana:

$$
\begin{aligned}
& X_{t}=\text { Data aktual pada periode ke-t } \\
& F_{t}=\text { Peramalan pada periode ke-t } \\
& n=\text { Banyaknya data }
\end{aligned}
$$

Untuk menghitung nilai dari Mean Absolute Precentage Error (MAPE) menggunakan persamaan (5).

$$
M A P E=\frac{1}{n} \sum_{t=1}^{n} \frac{\left|X_{t}-F_{t}\right|}{\left|X_{t}\right|}
$$

Dimana:

$X_{t}=$ Data aktual pada periode ke-t

$F_{t}=$ Peramalan pada periode ke-t

$n=$ Banyaknya data

Untuk mengetahui keakuratan hasil peramalan dari evaluasi kinerja dalam suatu metode yang digunakan pada saat melakukan peramalan. Maka dalam penelitian ini untuk melihat keakuratan dari hasil 
peramalan menggunakan Mean Absolute Precentage Error (MAPE) dari data out sample. Tabel 1 adalah kriteria dari suatu hasil peramalan berdasarkan nilai Mean Absolute Precentage Error (MAPE).

Tabel 1. Kriteria Nilai MAPE

\begin{tabular}{cc}
\hline Nilai MAPE & Kriteria \\
\hline$<10 \%$ & Sangat Baik \\
\hline $10 \%-20 \%$ & Baik \\
\hline $20 \%-50 \%$ & Cukup Baik \\
\hline$>50 \%$ & Buruk \\
\hline
\end{tabular}

\subsection{Data}

Data yang digunakan dalam penelitian ini merupakan Data runtut waktu, dimana datanya dikumpulkan dari setiap bulannya. Dan dalam penelitian ini menggunakan data jumlah penumpang pesawat di Bandar udara Internasional Juanda dari bulan Januari 2014 - Desember 2020 sebanyak 84 data.

\subsection{Tahap Pengolatah Data}

Penelitian ini menggunakan metode Exponential Smoothing Event-Based, kemudian dilakukan pembagian data in-sample dan data out-sample. Data in-sample dari bulan Januari 2014 - Desembar tahun 2017 dan data out-sample adalah tahun 2018. Tujuannya agar mendapatkan model yang optimal untuk digunakan pada peramalan selanjutnya. Adapun tahapan pada penelitian ini adalah sebagai berikut:

a. Menampilkan analisis deksriptif dan membuat plot data time series dan mengidentifikasi apakah data tersebut memiliki pola data trend atau musiman.

b. Menentukan nilai $\boldsymbol{a}($ alfa) yang optimum dengan menggunakan trial dan eror pada data in sample berdasarkan nilai Mean Square Error (MSE) dan Mean Absolute Precentage Error (MAPE) terkecil.

c. Melakukan perhitungan menggunakan metode single exponential smoothing dengan menggunakan nilai $a($ alfa $)$ dari hasil perhitungan pada point $\mathrm{b}$.

d. Menghitung nilai indeks event dan grup indeks.

e. Menghitung model menggunakan metode Exponential Smoothing Event-Based

f. Membuat grafik perbandingan antara data actual dengan data forecasting.

g. Menghiung nilai error (nilai kesalahan) dengan menggunakan perhitungan Mean Square Error (MSE) dan Mean Absolute Precentage Error (MAPE) menggunakan data out sample.

h. Melakukan peramalan untuk periode yang akan datang.

\section{HASIL DAN PEMBAHASAN}

\subsection{Analisis Deskriptif}

Analisis deskriptif dilakukan dengan tujuan untuk memberikan suatu gambaran atau informasi mengenai data jumlah penumpang pesawat di Bandar udara Internasional Juanda pada Januari 2014 Desember 2020. Data terbebut dibagi menjadi dua bagian, yaitu data training dan data testing. Untuk data training pada periode Januari 2014 - Desember 2017 mempunyai total data sebanyak 48 data, sedangkan untuk data testing dengan menggunakan periode tahun Januari 2018 - Desember 2020 mempunyai total data sebanyak 36 data. Gambar 2 merupakan plot dari data jumlah penumpang pesawat terbang di Bandar Udara Internasional Juanda pada periode 2014-2020 pada special event. 


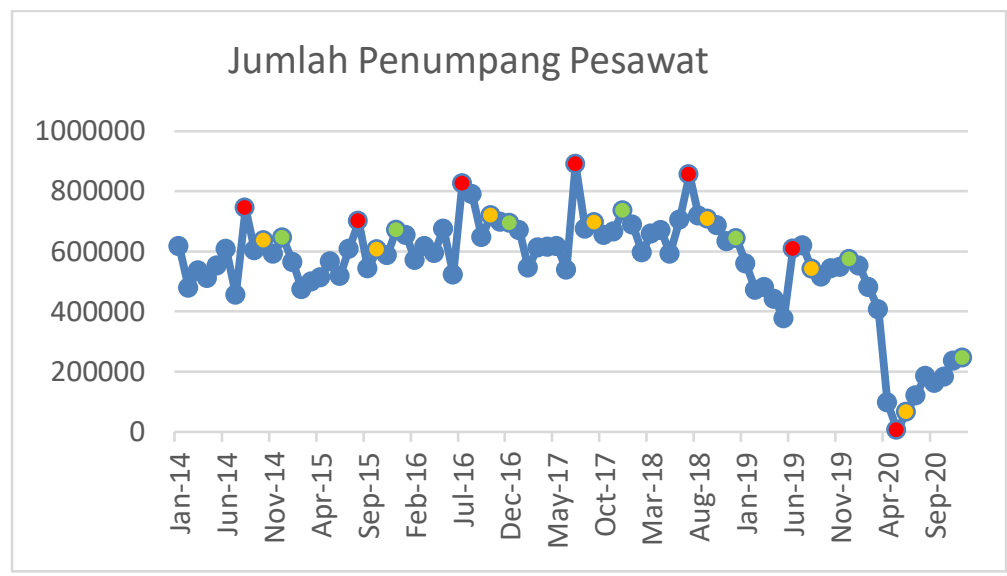

Gambar 1. Plot Data Jumlah Penumpang Pesawat Tahun 2014-2020

Dari Gambar 1 terlihat grafik menunjukkan bahwa pola data dari jumlah penumpang pesawat terbang di Bandar Udara Internasional Juanda memiliki pola data musiman, karena pada setiap tahunnya terjadi pola data yang sama dimana terpengaruhi oleh factor musim. Faktor musim yang terjadi salah satu penyebabnya adalah special event atau waktu-waktu tertentu pada gambar 2 ditandai menggunakan warna merah untuk Hari Raya Idul fitri, warna Kuning untuk Hari Raya Idul Adha, dan warna hijau untuk Libur Natal.

Pola data pada saat tahun 2014-2019 sebelum terjadinya pandemic selalu terjadi lonjakan penumpang pada special event. Namun memasuki special event di tahun 2020 terjadi perubahan yang sangat drastis, yakni penurunan yang sangat tajam terjadi bulan Mei 2020 (pada data ke-77) karena pada masa tersebut terjadi pandemic covid-19 (Corona virus Disease-2019) yang melanda dunia, yang mengharuskan masyarakat untuk membatasi aktivitas di luar rumah dengan melakukan social distancing. Di Indonesia, untuk mencegah penyebaran virus covid-19, Presiden Joko Widodo mengeluarkan himbuan agar masyarakat tidak melakukan mudik, karena masyarakat Indonesia mempunyai sebuah budaya pada saat Hari Raya Idul Fitri melakukan mudik ke kampung halaman [22]. Sehingga jumlah penumpang pada saat bulan Mei Tahun 2020 menjadi titik grafik terendah.

\subsection{Pemodelan Peramalan Menggunakan Exponential Smoothing Event Based}

Pada metode Exponential Smoothing Event-Based, langkah analisis pertama yang dilakukan adalah membagi data menjadi data in sample dan data out sample. Kemudian menentukan nilai a (alpha), tujuan dari menentukan nilai $a$ (alpha) adalah digunakan untuk membentuk model Single Exponential Smoothing. Dilakukan proses trial dan error atau dimulai dengan cara mencoba-coba nilai $a$ (alpha) $=0,1$ dan untuk percobaan selanjutnya dilakukan penambahan nilai 0,1 . Akan tetapi nilai dari $a$ (alpha) harus berada diantara 0 sampai dengan 1, karena berlaku $0<\alpha<1$. Hasil trial dan eror menggunakan Microsoft excel dapat dilihat pada Tabel 2.

Tabel 2. Hasil Trial dan Eror nilai $a$

\begin{tabular}{ccc}
\hline $\boldsymbol{a}$ (alpha) & $\boldsymbol{M S}_{\text {in sample }}$ & $\boldsymbol{M A P E}_{\text {in sample }}$ \\
\hline 0,1 & 3995541502,5417 & $10,1372 \%$ \\
\hline 0,2 & 3753453004,3287 & $9,8318 \%$ \\
\hline 0,3 & 36542629604,3419 & $9,6769 \%$ \\
\hline 0,4 & 3687909522,7028 & $9,6938 \%$ \\
\hline 0,5 & 3819049038,9416 & $9,8377 \%$ \\
\hline 0,6 & 4101440697,9465 & $10,1880 \%$ \\
\hline 0,7 & 4459888554,7365 & $10,6360 \%$ \\
\hline 0,8 & 4871203657,7143 & $11,1344 \%$ \\
\hline 0,9 & 5440580612,3565 & $11,7840 \%$ \\
\hline
\end{tabular}

Dapat dilihat dari Table 2 untuk membentuk suatu model Single Exponential Smoothing adalah dengan menggunakan nilai $a$ (alpha) yang optimal, dan nilai 0,3 merupakan nilai $a$ (alpha) yang optimal. Karena memiliki nilai $M S E_{\text {in sample }}$ dan nilai $M A P E_{\text {in sample }}$ terkecil dengan nilai sebesar 36542629604,3419 dan $9,6769 \%$. Selanjutnya dilakukan perhitungan untuk mengidentifikasi event, menghitung nilai dari indeks event, dan grup indeks. Hasil dari identifikasi dan perhitungan dapat dilihat pada Tabel 3. 
Tabel 3. Nilai Perhitungan Indeks Event dan Grup Event

\begin{tabular}{cccc}
\hline Special Event & Periode & Indeks Event & Grup Indeks \\
\hline & Jul-14 & 0,8021 & \\
\hline & Jul-15 & 1,1327 & 1,0905 \\
\hline Hari Raya Idul & Jul-16 & 1,3838 & \\
\hline Fitri & Jun-17 & 0,8615 & \\
\hline & Jun-18 & 1,0975 & \\
\hline & Jun-19 & 1,2656 & \\
\hline & Okt-14 & 1,0615 & \\
\hline Hari Raya Idul & Sep-15 & 0,9072 & \\
\hline Adha & Sep-16 & 0,9231 & \\
\hline & Sep-17 & 1,0182 & \\
\hline & Agu-18 & 1,0003 & \\
\hline & Agu-19 & 0,9867 & \\
\hline & Des-14 & 1,0650 & \\
\hline & Des-15 & 1,1391 & \\
\hline & Des-16 & 0,9938 & \\
\hline & Des-17 & 1,0907 & \\
\hline & Des-18 & 0,9361 & \\
\hline & Des-19 & 1,0586 & \\
\hline
\end{tabular}

Pada Tabel 3 untuk tahun 2020 tidak dilakukan perhitungan untuk indeks event dan grup indeks, karena pada tahun 2020 terjadi penurunan data jumlah penumpang yang signifikan akibat dari wabah yang melanda dunia yaitu covid-19 (Corona virus Disease-2019). Jadi meskipun dilakukan perhitungan tidak akan berpengaruh terhadap special event, karena special event tidak berpengaruh pada tahun tersebut.

Berdasarkan Tabel 3 terlihat bahwa special event berpengaruh pada penumpang pesawat adalah Hari Raya Idul Fitri tahun 2016, Hari Raya Idul Adha tahun 2014 dan Libur Natal tahun 2015. Untuk keseluruhan dari special event Hari Raya Idul Fitri dan Libur Natal merupakan special event yang berpengaruh karena, memiliki nilai Grup Indeks lebih dari 1. Model yang terbentuk dari dari metode Exponential Smoothing Event-Based adalah berikut:

Peramalan pada special event saat Hari Raya Idul Fitri

$$
P_{t+1}=1,0905\left[0,3 X_{t}+(1-0,3) F_{t}\right]
$$

Peramalan pada special event saat Hari Raya Idul Adha

$$
P_{t+1}=0,9828\left[0,3 X_{t}+(1-0,3) F_{t}\right]
$$

Peramalan pada special event saat Libur Natal

$$
P_{t+1}=1,0472\left[0,3 X_{t}+(1-0,3) F_{t}\right]
$$

Untuk melakukan perhitungan menggunakan metode Exponential Smoothing Event-Based dapat menggunakan model diatas ketika didalamnya terdapat waktu-waktu yang memuat special event, namun apabila terdapat waktu-waktu yang tidak mengandung special event maka perhitungannya dapat dilakukan secara biasa menggunakan persamaan umum dari metode single exponential smoothing. Berikut merupakan grafik perbandingan data aktual dengan data forecasting yang telah dilakukan, dapat dilihat pada Gambar 2 . 


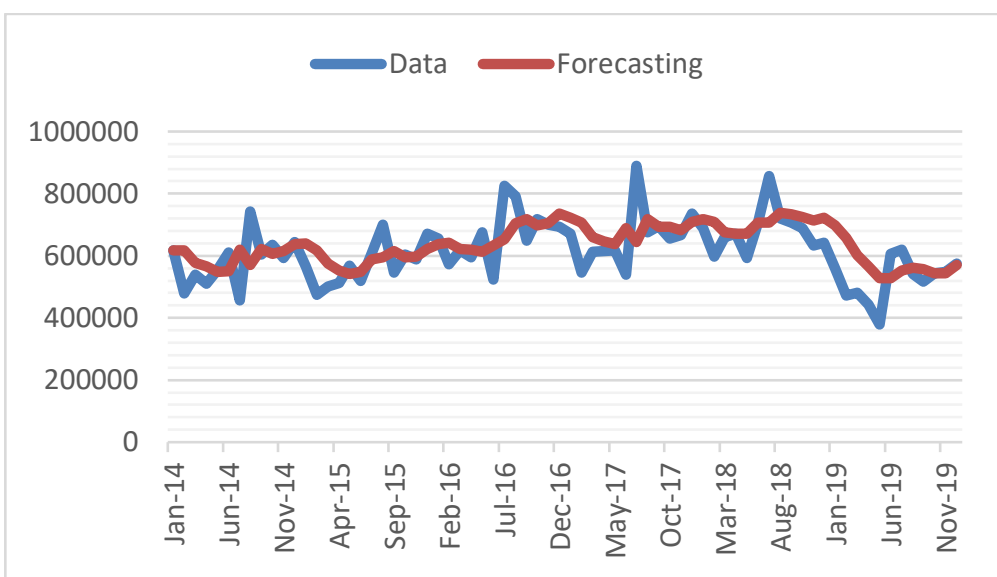

Gambar 2. Perbandingan data actual dan data forecasting

Gambar 2 merupakan grafik perbandingan antara data aktual dengan data forecasting dengan menggunakan metode Exponential Smoothing Event-Based. Dapat dilihat secara umum dari plot data yang terbentuk beberapa periode plot yang menunjukkan perbedaan antara data aktual dengan forecasting, walaupun terdapat juga beberapa periode pada plot data yang sama antara data aktual dengan data forecasting.

\subsection{EROR (Kesalahan Peramalan)}

Tabel 3 merupakan hasil dari ukuran ketepatan metode Exponential Smoothing Event-Based dari data out sample pada Januari 2018 - Desember 2019 dengan menggunakan Mean Square Error (MSE) dan Mean Absolute Precentage Error (MAPE).

\begin{tabular}{cc}
\multicolumn{2}{c}{ Tabel 4. Nilai Eror } \\
\hline \multicolumn{2}{c}{ Nilai Eror } \\
\hline MSE & MAPE \\
\hline 4202958561,0706 & $11,8905 \%$ \\
\hline
\end{tabular}

Berdasarkan Tabel 4 dapat dilihat bahwa nilai Mean Absolute Precentage Error (MAPE) yang diperoleh adalah $>10 \%$ dengan nilai sebesar 13,87\%. Dapat dikatakan metode Exponential Smoothing EventBased tergolong model yang baik.

Tabel 5 merupakan hasil dari ukuran ketepatan metode Exponential Smoothing Event-Based dari data out sample pada Januari 2018 - Desember 2020 dengan menggunakan Mean Square Error (MSE) dan Mean Absolute Precentage Error (MAPE).

\begin{tabular}{cc} 
Tabel 5. Nilai Eror \\
\hline \multicolumn{2}{c}{ Nilai Eror } \\
\hline MSE & MAPE \\
\hline 7206618162,4784 & $245,3085 \%$ \\
\hline
\end{tabular}

Berdasarkan Tabel 5 dapat dilihat bahwa nilai Mean Absolute Precentage Error (MAPE) yang diperoleh adalah $>100 \%$ dengan nilai sebesar $245,3085 \%$. Penyebab terjadinya nilai error yang sangat tinggi dari data out sample Januari 2018 - Desember 2020 dikarenakan penurunan data jumlah penumpang yang sangat signifikan pada tahun 2019 - 2020, sehingga menimbulkan nilai error yang sangat tinggi. Penurunan jumlah penumpang yang signifikan terjadi karena, terdapat suatu kejadian yang luar biasa dan dapat dikategorikan sebagai bencana alam internasional yaitu wabah covid-19.

\subsection{Peramalan}

Setelah didapatkan model permalan menggunakan metode Exponential Smoothing Event-Based, selanjutnya dari model tersebut akan dilakukan peramalan di tahun berikutnya. Tabel 6 merupakan hasil peramalan jumlah penumpang pesawat di bandara Juanda di Tahun 2021.

Tabel 6. Hasil Peramalan Jumlah penumpang Pesawat Tahun 2021

\begin{tabular}{cc}
\hline Periode & Forecasting \\
\hline Januari & 571273,7295 \\
\hline Februari & 571519,1838 \\
\hline
\end{tabular}




\begin{tabular}{cl}
\hline Maret & 570039,9599 \\
\hline April & 561380,8338 \\
\hline Mei & $\mathbf{5 9 2 5 7 6 , 4 3 1 7}$ \\
\hline Juni & 539229,4402 \\
\hline Juli & $\mathbf{4 5 7 0 4 5 , 7 2 9 5}$ \\
\hline Agustus & 385859,2672 \\
\hline September & 327162,1666 \\
\hline Oktober & 285738,0223 \\
\hline November & 254339,9496 \\
\hline Desember & $\mathbf{2 4 3 4 9 9 , 4 5 5 9}$ \\
\hline
\end{tabular}

Dari hasil peramalan di atas, Special event terjadi di bulan Mei (Idul Fitri), Juli (Idul Adha) dan Desember (libur Natal). Jumlah penumpang terbanyak terjadi di momen Idul Fitri. Pada momen Idul Adha tidak terlalu terjadi kenaikan yang signifikan, begitu pula saat libur Natal. Hasil peramalan tersebut masih dimungkinkan akan berubah jika ada kebijakan pemerintah terkait social distancing akibat pandemic covid19 yang saat ini sedang melanda dunia.

\section{KESIMPULAN}

Penelitian ini menggunakan metode Exponential Smoothing Event Based untuk meramalkan jumlah penumpang pesawat dengan memperhatikan special event pada hari-hari besar atau libur nasional tertentu, seperti saat menjelang dan sesudah Hari Raya Idul Fitri, Hari Raya Idul Adha dan libur Natal, yang memungkinkan terjadinya lonjakan penumpang. Dari model peramalan menggunakan parameter alpha $(\alpha)$ sebesar 0,3 dapat disimpulkan bahwa metode Event Based merupakan metode yang baik, karena mempunyai MAPE sebasar 11,8905 \% (dari data out sample pada Januari 2018 - Desember 2019). Untuk peramalan jumlah penumpang pesawat di Bandar Udara Internasional Juanda pada tahun 2021, jumlah penumpang pesawat mengalami penurunan dari bulan Januari hingga Desember akibat pandemic Covid-19 yang membuat pemerintah menerapkan kebijakan social distancing.

\section{DAFTAR PUSTAKA}

[1] Rahmat Gazali, “ini Alasan Jasa Angkutan Udara Lebih Diminati daripada Jasa Angkutan Laut,” borneonews.co.id, 2018. https://www.borneonews.co.id/berita/108431-ini-alasan-jasa-angkutan-udara-lebih-diminati-daripada-jasa-angkutan-laut (accessed Jan. 28, 2021).

[2] A. Darmanto, "Faktor yang Mempengaruhi Permintaan Jasa Transportasi Penyeberangan antar Pulau di Kota Raha," 2014.

[3] D. Kurnia, "7 Bandara Tersibuk di Indonesia, Sudah Pernah Mendarat di Sini?," Tiket.com, 2020. https://blog.tiket.com/bandara-tersibuk-di-indonesia/ (accessed Mar. 15, 2021).

[4] S. Yuliardi, "Tiga Bandara Indonesia Raih Penghargaan Dunia," wartaekonomi.co.id, 2018. TIGA BANDARA ANGKASA PURA I RAIH PENGHARGAAN PRESTISIUS DUNIA ASQ AWARDS 2017, BANDARA I GUSTI NGURAH RAI BALI RAIH PREDIKAT “BEST AIRPORT 2017” (accessed Jan. 28, 2021).

[5] R. Withycombe, "Forecasting with combined seasonal indices," Int. J. Forecast., vol. 5, no. 4, pp. 547-552, 1989, doi: 10.1016/0169-2070(89)90010-1.

[6] A. G. Salman and B. Kanigoro, "Visibility Forecasting Using Autoregressive Integrated Moving Average (ARIMA) Models," Procedia Comput. Sci., vol. 179, no. 2019, pp. 252-259, 2021, doi: 10.1016/j.procs.2021.01.004.

[7] D. K. Barrow, "Forecasting intraday call arrivals using the seasonal moving average method," J. Bus. Res., vol. 69, no. 12, pp. 6088-6096, 2016, doi: 10.1016/j.jbusres.2016.06.016.

[8] I. N. Putra, I. N. Pujawan, and N. I. Arvitrida, "Peramalan Permintaan Dan Perencanaan Produksi Dengan Mempertimbangkan Special Event Di Pt . Coca-Cola Bottling Indonesia ( Pt . Ccbi ) Plant-Pandaan,” peramalan permintaan dan Perenc. produksi dengan mempertimbangkan Spec. event di PT.COCA-COLA BOTTLING Indones. PLANT-PANDAAN, pp. 1-13, 2006.

[9] S. Henifa, "Peramalan Penjualan Avtur dengan Mempertimbangkan Special Event," 2014.

[10] S. Dheviani and P. Hendikawati, "Peramalan Banyaknya Penumpang Di Bandar Udara Internasional Ahmad Yani Semarang Dengan Mempertimbangkan Special Event," Prisma, vol. 1, pp. 434-444, 2018.

[11] F. A. Widjajati, "Menentukan Penjualan Produk Terbaik di Perusahaan X Dengan Metode Winter Eksponensial Smoothing dan Metode Event Based," Limits J. Math. Its Appl., vol. 14, no. 1, p. 25, 2017, doi: 10.12962/limits.v14i1.2127.

[12] M. R. F. Payu and N. Nurwan, "Metode Exponential Smoothing Event Based (Eseb) Dan Metode Winter'S Exponential Smoothing (Wes) Untuk Peramalan Jumlah Penumpang Tiba Di Pelabuhan Penyeberangan Gorontalo," BAREKENG J. Ilmu Mat. dan Terap., vol. 13, no. 3, pp. 197-202, 2019, doi: 10.30598/barekengvol13iss3pp197-202ar935.

[13] Sudjana, Metode Statistika. Bandung: Tarsito, 1986.

[14] Makridakis, S., Wheelwright, S. C., Hyndman, R. J., Forecasting: Methods and Applications. New York: John Wiley, 1998.

[15] P. M. Maçaira, R. C. Souza, and F. L. Cyrino Oliveira, "Modelling and forecasting the residential electricity consumption in 
Brazil with pegels exponential smoothing techniques," Procedia Comput. Sci., vol. 55, no. Itqm, pp. 328-335, 2015, doi: 10.1016/j.procs.2015.07.057.

[16] R. Biri, Y. A. . Langi, and M. S. Paendong, "Penggunaan Metode Smoothing Eksponensial Dalam Meramal Pergerakan Inflasi Kota Palu," J. Ilm. Sains, vol. 13, no. 1, p. 68, 2013, doi: 10.35799/jis.13.1.2013.2035.

[17] Aden, Forecasting The Eksponetial Smoothing Methods, no. 1. 2020.

[18] Taylor W. James, "Exponential smoothing with a damped multiplicative trend," Int. J. Forecast., vol. 19, no. 4, pp. 715-725, 2003.

[19] I. Falani, "Penentuan Nilai Parameter Metode Exponential Smoothing Dengan Algoritma Genetik Dalam Meningkatkan Akurasi Forecasting," Comput. Eng. Sci. Syst. J., vol. 3, no. 1, p. 14, 2018, doi: 10.24114/cess.v3i1.8268.

[20] D. W. Bunn and A. I. Vassilopoulos, "Using group seasonal indices in multi-item short-term forecasting," Int. J. Forecast., vol. 9, no. 4, pp. 517-526, 1993, doi: 10.1016/0169-2070(93)90078-2.

[21] J. S. Armstrong and F. Collopy, "Error measures for generalizing about forecasting methods: Empirical comparisons," Int. J. Forecast., vol. 8, no. 1, pp. 69-80, 1992, doi: 10.1016/0169-2070(92)90008-W.

[22] D. Andaka, "DAMPAK PELARANGAN MUDIK AKIBAT PANDEMI COVID19 dan sebagian kawasan lainnya masih menunjukkan peningkatan yang signifikan . peningkatan Kementerian Perhubungan dalam bentuk Peraturan Menteri Perhubungan ( Permenhub ) Nomor," vol. 1, no. 2, pp. 116-129, 2020. 